\title{
Poverty Alleviation Based On Economic Literacy And Social Capital In Improving Economic Welfare In Coastal Communities North Minahasa Regency, North Sulawesi Provence, Indonesia
}

\author{
Henry J.D. Tamboto ${ }^{1}$, Allen A.Ch. Manongko ${ }^{2}$, James J. Manengkey ${ }^{3}$ \\ Faculty of Economics, Manado State University, Indonesia
}

\begin{abstract}
The research problem is related to the economic welfare of coastal communities who are fishermen. The fundamental thing of this research is that poverty from the fishermen's household community is thought to be caused by inability to manage income and lack of horizontal relations between fellow communities. So that underlies various research findings, providing space for the concept of economic literacy and social capital can explain its influence on the economic welfare of the community. This research generally attempts to produce new methods and theories and policies in addressing the problems of coastal communities.This study aims to: 1). Analyzing and explaining partially the influence of economic literacy and social capital on the economic welfare of coastal communities; and 2). Analyze and explain simultaneously the influence of economic literacy and social capital on the economic welfare of coastal communities. The population in this study were all coastal communities (fishing communities) in North Minahasa Regency,North Sulawesi province,Indonesia. Number of samples from the calculation through the formula of Daniel and Terrel obtained 100 respondents. Sampling using purposive sampling technique. And data analysis using multiple regression, with SPSS application. The findings of this study indicate that: 1). economic literacy has a significant effect on economic prosperity; 2). social capital has a significant effect on economic welfare; 3 ). economic literacy and social capital have a significant effect on economic prosperity;
\end{abstract}

Keywords: Coastal Society, Economic Literacy, Social Capital, Economic Welfare

\section{Introduction}

The Central Statistics Agency (BPS, 2013) released data on the poor in Indonesia as many as 28 million people. 17 million of them are poor people in rural areas, 56 percent of whom are dependent on farming. The results of the 2013 agricultural census inform the number of farmer and fisherman households in Indonesia as many as 26,135,469 households that are working in the agriculture and fisheries sub-sectors. The average household income data of farmers has an income of Rp. 12,414,000 in a year or Rp. 1,034,500 / month (Agricultural Census 2013 - BPS RI). However, the Central Statistics Agency (BPS-2016) published the Indonesian economy in 2016 as measured by Gross Domestic Product (GDP) at current prices reaching Rp. 12,406.8 trillion, with per capita income reaching Rp. 47.96 million or 3,605, 1 US dollar. Based on the information above, it gives a very striking difference regarding the average income of farmer / fisherman households with Indonesia's cumulative income per capita.

Some notes that become a focus of the problem are how fishermen's households can enjoy life as enjoyed by the average population with an income of Rp. 47.96 million or 3,605.1 US dollars. The complexity of development in coastal villages that involves so many factors provides limited options for applying theory choices and community empowerment models. The problem of poverty is not a new phenomenon for the people of Indonesia. Poverty is a liquid concept, and is multi-dimensional. Resource economists see the poverty of coastal communities, especially fishermen, mostly due to socio-economic factors related to the characteristics of resources and the technology used. These things are what causes people who are fishermen in conditions of poverty. Kusnadi (2003) said the poverty trap that hit fishermen's life was caused by 
complex factors. Coastal communities with fisherman farmers' household communities are part of the Indonesian community that has not received much attention in development policies.

Various common problems hit this nation, including (1) poverty, social inequality, and economic pressures that come at any time, (2) limited access to capital, technology and markets, thus affecting business dynamics, (3) weaknesses in functions Existing socio-economic institutions, (4) low quality of human resources as a result of limited access to education, health, and public services, (5) degradation of environmental resources, both in coastal, marine and small islands, and (6) not yet the strength of maritimeoriented policies as the main pillar of national development (Kusnadi, 2009).

Capital is the main element in supporting increased production and living standards of the coastal community itself. This lack of capital greatly reduces the business activities of coastal communities, which are aimed at improving welfare through increased income (Kasryno, 1984). Hisbullah (2006) describes one positive variable that affects welfare is the existence of community capital as social capital owned by coastal communities. Hisbullah (2006) gives consideration to indications that social capital is participation in a network; reciprocity; trust; social norms; values; and proactive actions. Social capital can be a stimulant capital owned by the fishing community to open up opportunities and other capital potential. Social capital can be a potential as well as energy in bridging and strengthening even stimulating other capital potentials in a community. In essence, social capital becomes a potential that can be optimized by individuals in a community to get out of the problems faced. Social capital can be the basis and determinant of an orderly and prosperous society

In addition to social capital, efforts to provide reinforcement for farmer / fisherman households can be in the form of a learning process that aims to provide skills in economic studies related to the utilization and management of economic resources that are efficient and effective and economical. Learning that is still formally carried out in regular (formal) education can be used as a consideration in informal and informal learning, namely economic literacy. Yunus, et al. (2010) conducted research on economic literacy, which aims to find out whether economic education, savings, expenditure and investment have a relationship with economic literacy and to measure the extent to which economic education, savings, expenditure and investment affect economic literacy. Learning economic literacy is carried out through experience and planting attitudes, to shape individuals as effective and efficient economic actors in the family environment. This learning is non-formal, characterized by plans that are not systematic, unscheduled and not clearly defined, targets and objectives.

Based on the above problems, this study aims to examine and analyze partially and simultaneously the influence of economic literacy and social capital on the economic welfare of coastal communities in North Minahasa Regency, North Sulawesi Province

\section{Literature Review}

Economic Welfare

According to Maslow, family welfare is measured by the quality of resources (physical and nonphysical), while the World Bank (2004) measures family welfare seen from the expenditure proxy. According to WHO (Santamarina et al., 2002: 97), there are six categories of welfare, namely: 1) Physical;

2) Psychological; 3) Level of Independence; 4) Social Relations; 5) Environment; and 6) Spiritual.

Nationally, there are two versions of welfare measurement, namely welfare measures carried out by the Central Statistics Agency (BPS) and the National Family Planning Coordinating Board (BKKBN). BPS, for example, measures welfare seen from the concept of the minimum (calorie) proxy expenditure requirement, which is an average of Rp. 152,847, - per capita per month (SUSENAS, 2006), while BKKBN divides family welfare into three needs, namely: 1) basic needs consisting of food, clothing, housing and health; 2) psychological social needs consisting of education, recreation, transportation, internal and external social interaction; and 3) deve lopment needs consisting of savings, special / vocational education, and access to information

\section{Economic Literacy}

Budiwati (2014), revealed that economic literacy is a concept that becomes important, because with economic literacy means having intelligence in carrying out economic actions. In accordance with the principles of efficiency developed in economics, a high level of economic literacy implies acting on the economy (both production, consumption and distribution) based on rational economic principles. Wulandari 
(2011) that economic literacy is a life skill that must be owned by anyone to make the right economic decisions. Therefore, economic literacy can be applied to individual and household contexts.

In this modern diera economic decision-making process, the main thing is that someone must be smart. The indication is the ability to mix the resources they have to create benefits. For the creation of values that are crystallized in behavior economic literacy is needed, because in principle economic literacy is a useful tool to change behavior from not smart to smart. Like how to use income to save, invest, protect and fulfill life's needs. Making smart economic decisions is an option, and this choice requires effort. In addition to efforts, individuals also need to understand the right conditions to make daily economic decisions. Regarding these efforts and requirements, economic literacy becomes an option that should be owned by someone. In fact, not everyone has sufficient economic literacy to make smart decisions (Peter Sina, 2012). The study of economic literacy in this study is indicated by the knowledge, attitudes and skills of farmer households in managing business results efficiently, effectively and economically.

\section{Social Capital.}

Social capital can be simply defined as a set of informal values or norms that are shared among members of a group that allows cooperation between them (Fukuyama. 2002). Cohen and Prusak (2001) in Hasbullah (2006) provide an understanding that social capital is a stock of active relations between communities. Every pattern of relationship that occurs is bound by trust, mutual understanding and shared values that bind group members to make the possibility of joint action carried out efficiently and effectively. Some dimensions of social capital are explained in Hasbullah (2006) consisting of: Participation in a Network; Reciprocity; Trust; Social norms; Values; and Proactive Actions.

The hypothesis in the study:

1. There is an influence of economic literacy and social capital on the economic welfare of coastal communities in North Minahasa Regency, North Sulawesi Province.

2. There is an influence of economic literacy on the social capital of coastal communities in North Minahasa District, North Sulawesi Province.

3. There is an influence of economic literacy and social capital on the economic welfare of coastal communities in North Minahasa Regency, North Sulawesi Province.

\section{Research Method}

In this study designed with a quantitative approach through survey methods. research variable consists of:

1) Independent Variable, i.e. a) Economic Literacy, with indicators: Affective; Cognitive; and Psychomotor.

b) Social Capital, with Indicators: Participation in the Network; Reciprocity; Trust; Social norms; Values; Proactive Action.

2) Dependent Variables, namely Economic Welfare, with indicators: 1) basic needs consisting of food, clothing, housing and health; 2) psychological social needs consisting of education, recreation, transportation, internal and external social interaction; and 3) development needs consisting of savings and access to information. Measurement scale: Likert. Sampling by using the formulas from Daniel and Terrel (1989) with an error rate set at 5 percent. The calculation results obtained by the research sample were 100 samples.

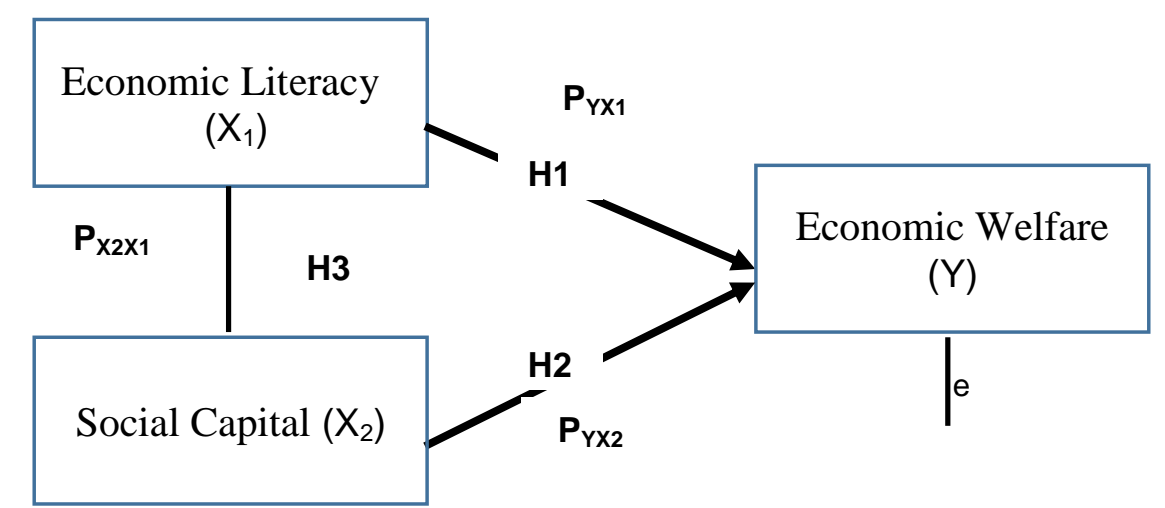

Figure 1. Conceptual Framework 
The research instrument used a questionnaire, with a list of closed questions and statements. The measurement scale uses a Likert scale (5 alternative answers). Instrument testing by testing validity and reliability (SPSS 16 program application). Validity test by comparing Pearson product moment correlation index with a significance level of 5\% with its critical value. Validated valid if the value of $r_{x y} \geq 0,2185$ and if the value of rxy $\leq 0.2185$ is declared invalid (Sugiyono, 2007). Reliability test using Cronbach alpha. It is stated reliably if the value of Cronbach's Alpha is 60.6 and if the value of Cronbach's Alpha is $\leq 0.6$ it is declared unreliable (Sugiyono, 2007).

\section{Results and discussion}

Result

The equation obtained ( 1 ) is: $\mathrm{Y}=13.121+0.517 \mathrm{X} 1+\mathrm{e} 1$; where $\mathrm{e} 1=\sqrt{ } 1-0.549=0.672$ From the table above shows that the magnitude of the coefficient (obtained from the OLS beta coefficients) is 0.741, with a tcount of 10.932 and a Sig t of 0.000. Because thitung $>t$ table $(10.932>1.980)$ and Sig $t<0.05(0.000$ $<0.05)$ it can be concluded that there is an influence of economic literacy (X1) on economic welfare (Y). Because the coefficient is positive (0.741) indicating a positive relationship. This means that the higher the economic literacy (X1), the higher the economic welfare (Y) of coastal communities in North Minahasa regency in an effort to improve their situation. The amount of R Square value obtained is 0.549 or $54.9 \%$. This means that economic welfare (Y) is affected by $54.9 \%$ by economic literacy (X1), and the remaining $45.1 \%$ is influenced by other variables outside the variables studied.

The equation obtained ( 2$)$ is $: Y=4,312+0.560 X 2+\mathrm{e} 2$; where $\mathrm{e} 2=\sqrt{ } 1-0.824=0.42$

From the table above shows that the magnitude of the coefficient (obtained from the beta coefficient of OLS results) is 0.908 , with a tcount of 21.438 and a Sig $t$ of 0.000 . Because thitung $>t$ table $(21.438>1.980)$ and Sig $t<0.05(0.000<0.05)$ it can be concluded that there is an influence of social capital $(\mathrm{X} 2)$ on economic welfare (Y). Because the positive coefficient (0.908) indicates a positive relationship. This means that the higher the social capital (X2), the higher the economic welfare (Y) of the coastal communities in North Minahasa regency in an effort to improve their situation.

Furthermore, the contribution of social capital to explain economic welfare can be seen in the Model Summaryb table (the value of R Square)

Based on the results of regression analysis (empirical model) shows that the findings of this study are: 1). Economic literacy has a significant effect on the economic welfare of coastal communities in North Minahasa Regency, North Sulawesi Province, with the beta coefficient of 0.741 at a significance level of $0.000 ; 2)$. social capital has a significant effect on the economic welfare of coastal communities in North Minahasa Regency, North Sulawesi Province, with the beta coefficient of 0.908 at a significance level of 0.000; and 3). Economic literacy and social capital simultaneously affect the economic welfare of coastal communities in North Minahasa Regency, North Sulawesi Province. From these results it means that partially and simultaneously describe that independent variables (economic literacy and social capital) have the ability to explain the dependent variable (economic welfare) in this study.

\section{Hypothesis Testing}

Based on the results obtained indicate that the effect of Economic Literacy (X1) on Economic Welfare (Y) obtained a beta coefficient of 0.741 , with a value of $t$ count of 10.932 and a Sig $t$ of 0.000 . Because thitung $>\mathrm{t}$ table $(10.932>1.980)$ and Sig $\mathrm{t}<0.05(0.000<0.05)$ it can be concluded that there is a significant and positive influence of Economic Literacy (X1) on Economic Welfare (Y). Because the path coefficient is positive (0.741) indicating a positive relationship. This means that the higher the Economic Literacy $(\mathrm{X} 1)$, the higher the Economic Welfare (Y).

Based on the results obtained shows that the effect of Social Capital (X2) on Economic Welfare Decisions (Y) is obtained by the beta coefficient of 0.980 , with tcount of 21.438 and Sig t of 0.000 . Because thitung <ttable $(21.438>1.980)$ and Sig $\mathrm{t}<0.05(0.000<0.05)$ then it can be concluded that there is a significant and positive influence on Social Capital (X2) on Economic Welfare (Y). This means that increasing the value of Social Capital (X2), will also increase the value of Economic Welfare (Y).

The results of the F test using the SPSS program can be seen in the ANOVAb value. Hypothesis requirements can be accepted if Fcount $>$ Ftable or / and if $p$ Value $<0.05$ then H1 hypothesis is accepted and $\mathrm{H} 0$ is rejected. Simultaneous test results can be seen in the ANOVAb value below:

Based on the results of simultaneous tests obtained the value of Fcount $=231.899$ while Ftable $=1.91$. 
These results indicate that Fcount $=231.899>$ Ftable $=1.91$. And $p$ Value $0.000<0.05$, then according to the above conditions means the hypothesis states that simultaneously economic literacy variables (X1) and social capital (X2) significantly influence the economic welfare (Y) of coastal communities in North Minahasa Regency.

\begin{tabular}{|c|r|r|r|r|r|}
\hline $\begin{array}{c}\text { Mo } \\
\text { del }\end{array}$ & $\mathrm{R}$ & Square & $\begin{array}{c}\text { Adjusted R } \\
\text { Square }\end{array}$ & $\begin{array}{c}\text { Std. Error } \\
\text { of the } \\
\text { Estimate }\end{array}$ & $\begin{array}{c}\text { Durbin- } \\
\text { Watson }\end{array}$ \\
\hline 1 & $.909^{\mathrm{a}}$ & .827 & .823 & 2.55791 & 2.176 \\
\hline
\end{tabular}
a. Predictors: (Constant), X2, X1
b. Dependent Variable:Y

The results of the summaryb model show that the value of Adjusted R Square is equal to 0.823. This means that economic welfare can be explained by economic literacy and social capital by $82.3 \%$, and by $17.7 \%$ explained by variables or other factors outside this research.

\section{Discussion}

Effect of Economic Literacy on Economic Welfare.

Based on the test results obtained that the effect of Economic Literacy (X1) on Economic Welfare (Y) obtained a beta coefficient of 0.741 , with a tcount of 10.932 and a Sig t of 0.000 . Because thitung $>\mathrm{t}$ table $(10.932>1.980)$ and Sig $t<0.05(0.000<0.05)$ it can be concluded that there is a significant and positive influence of Economic Literacy (X1) on Economic Welfare (Y). Because the path coefficient is positive (0.741) indicating a positive relationship. This means that the higher the Economic Literacy (X1), the higher the Economic Welfare (Y).

This finding illustrates that learning economic literacy in the midst of society through experience and planting attitudes, can shape individuals as effective and efficient economic actors in the family environment. This learning is non-formal, characterized by plans that are not systematic, unscheduled and not clearly defined, targets and objectives. In line with Yunus's explanation, et al. (2010) conducted research on economic literacy, which aims to find out whether economic education, savings, expenditure and investment have a relationship with economic literacy and to measure the extent to which economic education, savings, expenditure and investment affect economic literacy. Also Peter G. Sina (2012), explained that economic literacy has a purpose as an effort to improve economic literacy for individuals and households who want to achieve prosperity. Therefore, the obligation to increase economic literacy needs to be done in a planned manner and starting from the intention to learn to improve economic literacy because it can have an effect on asset accumulation, proper debt management, protection, increasing savings and smartly managing expenses.

\section{Effect of Social Capital on Economic Welfare.}

Based on the results obtained shows that the effect of Social Capital (X2) on Economic Welfare Decisions (Y) obtained a beta coefficient of 0.980, with a value of t count of 21.438 and a Sig $t$ of 0.000 . Because thitung <ttable $(21.438>1.980)$ and Sig $t<0.05(0.000<0.05)$ then it can be concluded that there is a significant and positive influence on Social Capital (X2) on Economic Welfare (Y). This means that increasing the value of Social Capital (X2), will also increase the value of Economic Welfare (Y).

This finding explains that social capital can be a stimulant capital for the fishing community to open up opportunities and other capital potential. The concept of social capital, which was originally understood as a form in which people put trust in the community and individuals as part of it, they made mutual agreement as a value in their community. This is in line with the opinion of Hisbullah (2006) that one of the positive variables that affect welfare is the existence of community capital as social capital owned by the coastal community. Hisbullah (2006) gives consideration to indications of social capital as participation in a network; reciprocity; trust; social norms; values; and proactive actions. This was explained by Nasution (2007) that community-based natural resource management based on the strength of community social 
capital itself has been proven to reduce selfish and free rider attitudes, and ultimately tends to be more effective towards sustainable resource utilization.

\section{Effect of Economic Literacy and Social Capital on Economic Welfare.}

Based on the results of simultaneous tests obtained the value of Fcount $=231.899$ while Ftable $=1.91$. These results indicate that Fcount $=231.899>$ Ftable $=1.91$. And $p$ Value $0.000<0.05$, then according to the above conditions means the hypothesis states that simultaneously economic literacy variables (X1) and social capital (X2) significantly influence the economic welfare (Y) of coastal communities in North Minahasa Regency. With a real contribution of 0.823 . This means that economic welfare can be explained by economic literacy and social capital by $82.3 \%$, and by $17.7 \%$ explained by variables or other factors outside this research.

These findings prove that economic literacy is indicated by the knowledge, attitudes and skills of farmer households in managing business results efficiently, effectively and economically, and social capital indicated as participation in a network; reciprocity; trust; social norms; values; and proactive actions, can give a significant influence and positive relationship to the economic welfare of coastal communities in North Minahasa Regency, North Sulawesi Province.

These results are in line with Budiwati's (2014) opinion; Peter G. Sina (2012); Wulandari (2011); Mathews (1999); Hasbullah (2006); and (Fukuyama. 2002), that economic literacy is a concept that becomes important, because with economic literacy means having intelligence in carrying out economic actions. In accordance with the principles of efficiency developed in economics, a high level of economic literacy implies acting on the economy (both production, consumption and distribution) based on rational economic principles. Economic literacy is a life skill that must be owned by anyone to make the right economic decisions. Therefore, economic literacy can be applied to individual and household contexts. The low level of economic literacy will have an impact on consumer attitudes towards society. In principle, economic literacy is a tool to achieve goals, only in reality not everyone has a high economic literacy, thus purifying opportunities for prosperity. One indicator is to be an intelligent person in managing economic resources to achieve prosperity. Likewise, social capital is a positive aspect as well as community capital in improving community welfare. Efforts to improve the welfare of coastal communities in a planned and structured manner have been implemented by the government through programs that directly touch the people in coastal areas that aim to improve the welfare of coastal communities through empowering communities and utilizing coastal and marine resources optimally and sustainably

\section{Conclusion and Recommendation}

Based on the results of the study, the conclusions of this study are as follows: a. Economic literacy has a significant influence on the economic welfare of coastal communities. This means that an increase in the economic literacy coefficient will give a positive increase to the economic prosperity of the pesisisr community in North Minahasa Regency.

b. Social capital has a significant influence on the economic welfare of coastal communities. This means that the increase in the coefficient of social capital will provide a positive increase in the economic prosperity of pesisisr communities in North Minahasa Regency.

c. Economic literacy and social capital together have a significant effect on the economic prosperity of pesisisr communities in North Minahasa Regency.

Suggestion

Based on the results of the research, suggestions in the study are as follows:

1) The findings of this study are still in conceptual and methodological form, so that the implementation has not been so strong. For this reason, further research is needed to review the variables that contributed to this study.

2) The findings of this study, the sample data analyzed is still small (small), so the ability to generalize is not so strong. For this reason, future research will increase the number of research samples.

\section{References}

[1] Balai Besar Riset Sosial Ekonomi. 2005. Indikator Kinerja Pembangunan Sektor Kelautan dan Perikanan: Executive Summary. BBRSE. Jakarta. 43 hal.

[2] BPS 2013. Statistik Indonesia. Kab. Minahasa Utara, 2013 
[3] Budiwati N, 2014.Pengembangan Model Pembelajaran Berbasis Literasi Ekonomi (Studi pada Pembelajaran Ekonomi di SMA Negeri Kota Bandung). Repository UPI. Bandung

[4] Cernea, M.M. 1988. Sosiologi Untuk Proyek-Proyek Pembangunan, dalam M.M. Cernea (Ed). Mengutamakan Manusia Dalam Pembangunan; Variabel-Variabel Sosiologi di dalam Pembangunan Pedesaan. Publikasi Bank Dunia. Penerjemah; B.B.Teku. Universitas Indonesia Press. Jakarta. Hal: 3-26

[5] Coleman, J.S. 1988. Foundations of social Theory. Cambridge: Harvad University Press.

[6] Cullen, Michelle and Harvey Whiteford. 2001. The Interrelations of Social Capital with Health and Mental Health. Discussion Paper. Mental Health and Special Programs Branch Commonwealth Department of Health and Aged Care. Canberra : The Commonwealth Australia.

[7] Daniel, W.W, and Terrel, J.C. (1989). Business Statistics Fifth Edition. Houghton Mifflin Company. Boston

[8] Dasgupta dan Serageldin, ,2000, Social Capital, The World Bank, Washinton DC.

[9] Fukuyama Francis, 1995, Trust: The SOCIAL Virtue and The Creation of Properity, New York Free Press,

[10] Hasanudin, Basri.1985. "Beberapa Hal Mengenai Struktur Ekonomi Masyarakat Pantai”, dalam A.S. Achmad dan S.S. Acip (Peny.). Komunikasi dan Pembangunan. Jakarta: Penerbit Sinar Harapan, hal. 105-110.

[11] Hasbullah, J. 2006. Social Capital (Menuju Keunggulan Budaya Manusia Indonesia), Penerbit MRUnited Press Jakarta.

[12] Jamasy, Owin, 2004. Keadilan, Pemberdayaan \& Penanggulangan Kemiskinan. Jakarta: Belantika.

[13] Kinloch, G. C, 2005, Perkembangan danParadigma Utama : Teori Sosiologi: Pustaka Setia Bandung.

[14] Kusnadi. 2009. Keberdayaan The Netherlands.

[15] Peter Garlans Sina, 2012. Analisis Literasi Ekonomi. Jurnal Economia, Volume 8, Nomor 2, Oktober 2012

[16] Riduwan, dan Kuncoro. 2007. “Analisis Jalur Path Analysis: Cara Menggunakan dan Memakai”. Cetakan Kedua, Penerbit, Alfabeta.

[17] Soemardjan, Selo, 1986. Perubahan Sosial di Yogyakarta. Yogyakarta: Gadjah Mada University Press.

[18] Sugiyono, 2010, Metode Penelitian Pendidikan, Pendekatan Kuantitatif, Kualitatif dan R \&D, Alfabeta Bandung

[19] Todaro, M.P. 2000. Pembangunan Ekonomi di Dunia Ketiga. Edisi Ketujuh. Erlangga, Jakarta

[20] Uphoff, N, 2000. Understanding Social capital: Learning from the analysis and experience of participation. Di dalam Dasgupta P. Ismail S, 1999, editor. Social capital A Multifaceted Perspective. The world bank, Washington.

[21] Wahyono, H. 2001. Pengaruh Perilaku Ekonomi Kepala Keluarga Terhadap Intensitas Pendidikan Ekonomi di Lingkungan Keluarga. Disertasi, Pascasarjana Universitas Negeri Malang

[22] Nelayan dan Dinamika Ekonomi Pesisir. Pusat Penelitian Wlayah Pesisir Dan Pulau-Pulau Kecil. Jember: Lembaga Penelitian Universitas Jember.

[23] Masyhuri Imron dan M. Azzam Manan. 2009. Strategi Nelayan dalam Peningkatan Kesejahteraan. LIPI. Jakarta.

[24] Mubiyarto, dkk, 1984, Nelayan dan Kemiskinan Radjawali Press, Jakarta

[25] Nakajima, C. 1986 Subjective Equilibrium Theory Of The Farm Household. Developments in Agricultural Economics. Elsevier Science Publisher B.V. Printed in 